\title{
Evidence of nitrogen and potassium losses in soil columns cultivated with maize under salt stress
}

\author{
Claudivan F. de Lacerda ${ }^{1}$, Jorge F. da S. Ferreira ${ }^{2}$, Donald L. Suarez ${ }^{2}$, \\ Emanuel D. Freitas ${ }^{1}$, Xuan Liu ${ }^{2}$ \& Aureliano de A. Ribeiro ${ }^{1}$ \\ ${ }^{1}$ Universidade Federal do Ceará/Centro de Ciências Agrárias/Departamento de Engenharia Agrícola. Fortaleza, CE. E-mail: cfeitosa@ufc.br (Corresponding \\ author) - ORCID: 0000-0002-5324-8195; emanueldiasfreitas@gmail.com - ORCID: 0000-0002-8829-9486; alburibeiro@hotmail.com - ORCID: 0000- \\ 0001-5823-7615 \\ ${ }^{2}$ United States Department of Agriculture/US Salinity Laboratory. Riverside, California. E-mail: jorge.ferreira@ars.usda.gov - ORCID: 0000-0003-4550- \\ 6761; donald.suarez@ars.usda.gov - ORCID: 0000-0001-8583-2161; xuan.liu@ars.usda.gov - ORCID: 0000-0002-6952-0915
}

Key words:

salinity

nitrate

nutrients leaching

\begin{abstract}
A B S T R A C T
The aim of this study was to evaluate the accumulation of salts in the soil from irrigation water and of $\mathrm{N}$ and $\mathrm{K}$ from fertilization. The experiment was conducted in PVC columns $(20 \mathrm{~cm}$ in diameter and $100 \mathrm{~cm}$ in height), filled with non-saline soil, and cultivated with maize. A completely randomized block design in a $4 \times 4$ factorial was used, with four levels of salinity $\left(0.5,2.5,5.0\right.$ and $\left.7.5 \mathrm{dS} \mathrm{m}^{-1}\right)$, four $\mathrm{N}$ rates, and five replicates. Nitrogen was applied as urea and potassium nitrate at the following rates: N1: $\mathrm{N}$ recommendation for maize $\left(2.6\right.$ g column $\left.^{-1}\right) ; \mathrm{N} 2: 0.3$ times $\left(0.78\right.$ g column $\left.^{-1}\right)$ the recommended N1 dose; N3 and $\mathrm{N} 4$ with $\mathrm{N}$ based on $\mathrm{N} 1$ and $\mathrm{N} 2$ doses, respectively, reduced proportionally based on the evapotranspiration reduction caused by salinity. After 74 days from sowing, root and soil samples were collected at different soil depths. The electrical conductivity of the saturated extract (ECe) and the concentration of ions $\left(\mathrm{Ca}^{2+}, \mathrm{Na}^{+}\right.$, and $\left.\mathrm{Cl}\right)$ increased as a function of salinity and soil depth. The opposite was observed for the root system. The increase in salinity also resulted in $\mathrm{K}^{+}$and $\mathrm{NO}_{3}^{-}$accumulation in the soil column, mainly in treatments with higher $\mathrm{N}$ rates $(\mathrm{N} 1 \text { and } \mathrm{N} 3)^{3}$. At the end of the experiment, $88 \%$ of the $\mathrm{NO}_{3}^{-}$applied at the highest salinity treatment $\left(7.5 \mathrm{dS} \mathrm{m}^{-1}\right)$ and the highest $\mathrm{N}$ rate $(\mathrm{N} 1)$ was below $20 \mathrm{~cm}$ soil depth, evidencing a $\mathrm{N}$ loss process caused by leaching.
\end{abstract}

Palavras-chave:

salinidade

nitrato

lixiviação de nutrientes

\section{Evidências de perdas de nitrogênio e potássio em colunas de solo cultivadas com milho sob estresse salino}

\section{R E S U M O}

Objetivou-se com o trabalho avaliar o acúmulo no solo de sais provenientes da água de irrigação e de $\mathrm{N}$ e K provenientes da adubação. O experimento foi conduzido em colunas de PVC (20 $\mathrm{cm}$ de diâmetro e $100 \mathrm{~cm}$ de altura), preenchidas com solo arenoso, não salino, cultivado com milho. Utilizou-se delineamento em blocos inteiramente casualizados em arrajamento fatorial $4 \mathrm{x} 4$, composto por quatro níveis de salinidade $\left(0,5,2,5,5,0\right.$ e $\left.7,5 \mathrm{dS} \mathrm{m}^{-1}\right)$ e quatro doses de $\mathrm{N}$, com cinco repetições. As quatro doses de $\mathrm{N}$, aplicadas como ureia e nitrato de potássio, foram as seguintes: $\mathrm{N} 1$ : seguindo a recomendação de $\mathrm{N}$ para o milho $\left(2,6 \mathrm{~g}_{\text {coluna }}{ }^{-1}\right)$; $\mathrm{N} 2: 0,3$ vezes N1 (0,78 g coluna $\left.^{-1}\right)$; N3 e N4: Taxa reduzida de N1 e N2, respectivamente, com base na redução da evapotranspiração causada pela salinidade. Aos 74 dias após o plantio foram coletadas as raízes e amostras de diferentes camadas do solo. A condutividade elétrica do extrato saturado (CEes) e as concentrações de íons ( $\mathrm{Ca}, \mathrm{Na}$ e $\mathrm{Cl}$ ) aumentaram em função da salinidade e da profundidade. $\mathrm{O}$ contrário foi observado no sistema radicular. $\mathrm{O}$ aumento da salinidade provocou o acúmulo de $\mathrm{Ke} \mathrm{NO}_{3}^{-}$nas colunas de solo, principalmente nas maiores doses de $\mathrm{N}\left(\mathrm{N} 1\right.$ e N3). Para o tratamento de maior salinidade $\left(7,5 \mathrm{dS} \mathrm{m}^{-1}\right)$ e maior dose de $\mathrm{N}$ (N1) verificou-se que $88 \%$ do $\mathrm{NO}_{3}^{-}$encontrava-se abaixo de $20 \mathrm{~cm}$ do solo ao final do experimento, mostrando perda por lixiviação. 


\section{INTRODUCTION}

Salt-stress effects on plant development are mainly due to osmotic and toxic components, which cause reduction in stomatal opening, photosynthetic activity, nutrient uptake and balance, transpiration, and plant growth (Azevedo Neto \& Tabosa, 2000; Munns \& Tester, 2008; Willadino \& Camara, 2010; Prisco et al., 2016; Tagliaferre et al., 2016). The reduction in water uptake and plant (root and shoot) growth caused by salinity culminates with the reduced capacity of the plant to extract nutrients from the soil, especially those required in larger quantities by plants (Shenker et al., 2003; Ramos et al., 2012; Lacerda et al., 2016b).

Although positive responses to nutrient supplementation have been observed in plants under salt-stress ( $\mathrm{Hu}$ \& Schmidhalter, 2005), especially under conditions of low soil fertility (Grattan \& Grieve, 1999), these responses are not present at the same intensity as found in non-saline conditions (Irshad et al., 2008; Lacerda et al., 2016a,b), resulting in nutrient losses and reduced $\mathrm{N}$ use efficiency. As a consequence, a large percentage of the nutrients applied to the soil can be lost mainly by leaching, causing economic losses and contamination of ground water (Shenker et al., 2003; Segal et al., 2010; Ramos et al., 2012; Mendes et al., 2016). This problem is aggravated in the case of nutrients with high soil mobility, such as nitrate. The objective of this study was thus to measure and quantify the losses of $\mathrm{N}$ and $\mathrm{K}$ from soil cultivated with maize under salt-stress using soil columns.

\section{Material AND Methods}

The experiment was conducted at the US Salinity

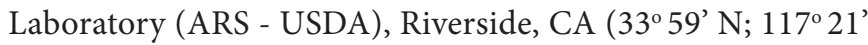
$\mathrm{W})$, from September $13^{\text {th }}$ to November $26^{\text {th }}, 2013$. During the experiment the average maximum, minimum, and average air temperature were $26.7,12.8$ and $20^{\circ} \mathrm{C}$, respectively. Maize plants were grown in columns of polyvinyl chloride (PVC) with $20 \mathrm{~cm}$ in diameter and $100 \mathrm{~cm}$ in length. Columns were filled with sieved (5-mm mesh) non-saline ( $\mathrm{EC}_{\mathrm{e}}$ of $\left.1.6 \mathrm{dS} \mathrm{m}^{-1}\right)$ sandy loam soil with $\mathrm{pH} 6.8$, collected from a site near to the experimental area. A nylon mesh and a cap adapted with a drainage pipe were attached to the bottom of each PVC tube to retain the soil, but allow the drainage water to pass and to be collected into 1-L glass bottles with wide mouths set below the drainage pipes (Lacerda et al., 2016b).

The experiment was conducted in a completely randomized block design following a $4 \times 4$ factorial arrangement, composed of four levels of salinity ( $\mathrm{S} 1=0.5 ; \mathrm{S} 2=2.5 ; \mathrm{S} 3=5.0$; and $\mathrm{S} 4$ $=7.5 \mathrm{dS} \mathrm{m}^{-1}$ ) and four $\mathrm{N}$ rates, with five replications. Saline treatments were obtained by adding $\mathrm{NaCl}, \mathrm{CaCl}_{2} \cdot 2 \mathrm{H}_{2} \mathrm{O}$, and $\mathrm{MgCl}_{2} \cdot 6 \cdot \mathrm{H}_{2} \mathrm{O}$ salts in a 7:2:1 molar charge ratio $\left(\mathrm{M}_{\mathrm{c}}\right)$, according to the approximate relationship between $\mathrm{EC}_{\mathrm{w}}$ and concentration $\left(\mathrm{mmol}_{\mathrm{c}} \mathrm{L}^{-1}=\mathrm{EC}_{\mathrm{w}} \mathrm{x} 10\right)$. Irrigation was performed every other day. During the experiment, two rain events occurred (13 and $25 \mathrm{~mm}$ ). The average leaching fraction for treatments S1, S2, S3 and $S 4$ were respectively, $0.16,0.17,0.19$, and 0.23 , considering both irrigation and rainfall quantities.

The four $\mathrm{N}$ rates, applied as urea and potassium nitrate, were as follows: N1: N recommendation for maize in California $\left(206 \mathrm{~kg} \mathrm{ha}^{-1}\right)$; N2: 0.3 times the $\mathrm{N}$ recommendation for maize in California $\left(62 \mathrm{~kg} \mathrm{ha}^{-1}\right), \mathrm{N} 3$, reduction based on N1 considering the decrease in evapotranspiration caused by salinity in the previous stage; N4, reduction based on N2 considering the decrease in evapotranspiration caused by salinity in the previous stage. The proportions of $\mathrm{N}$ for all treatments were described by Lacerda et al. (2016b).

The $\mathrm{N}$ and $\mathrm{K}$ application (120 kg ha-1 of $\mathrm{K}_{2} \mathrm{O}$ ) in each treatment was distributed during the vegetative growth stage as follows: $15 \%$ at sowing; $25 \%-20$ days after sowing (DAS); 30\%-35 DAS, and 30\%-50 DAS. The other nutrients were applied following technical recommendations for maize in California (Lacerda et al., 2016b).

Five seeds of maize (Zea mays L.) cv. Nothstine Dent OG Lot \# 41629 (Johnny's Selected Seeds, Winslow, ME, USA) were sown per column. Thinning was done seven DAS, leaving only one plant per column. The treatments with saline waters were initiated eight DAS.

Four soil samples per column, at different depths (0-20, $20-40,40-60$, and $60-80 \mathrm{~cm}$ ), were collected at the end of the experiment (74 DAS). The electrical conductivity of the soil saturation extract $\left(\mathrm{EC}_{\mathrm{e}}\right.$ ) was determined according to Richards (1954). The concentrations of nitrate, K, Na, Ca and $\mathrm{Cl}$ were also determined in the saturation extract. Concentrations of $\mathrm{K}, \mathrm{Na}$ and $\mathrm{Ca}$ were obtained by plasma optical emission spectrometry (AOAC, 1990), Cl by the methodology given by Gaines et al. (1984) and the nitrate concentration according to the salicylic acid method (Cataldo et al., 1975). The root biomass of each soil column was also measured at the end of the experiment.

The differences among salt treatments, $\mathrm{N}$ application, and the interaction between salt and $\mathrm{N}$ were tested using a twoway analysis of variance (F test). The regression analysis and Tukey's test were used to evaluate the effects of salinity and $\mathrm{N}$ application, respectively.

\section{Results AND Discussion}

The results of the analysis of variance related to the effects of salinity $(\mathrm{S})$ of the irrigation water, nitrogen rates $(\mathrm{N})$, and the interactions between $\mathrm{S} x \mathrm{~N}$, and between $\mathrm{S}$ and $\mathrm{N}$ with soil depth layers (L) are given in Table 1.

There was a statistically significant interaction at a $1 \%$ probability level (F test) between the salinity of the irrigation water and the soil layers for all parameters evaluated (ECe, salt, and mineral nutrients). Salinity of the irrigation water is one of the main factors that contributes to lesser utilization of nutrients by plants, thus increasing their accumulation in the soil. In turn, development of the root system is compromised due to the increased concentration of salts in the soil (Willadino \& Camara, 2010; Prisco et al., 2016; Santos et al., 2016; Tagliaferre et al., 2016).

The root dry mass (RDM) decreased with increasing soil depth and with the increased salinity of the applied water (Figure 1).

The data agree with previous observations that the plant root system, especially for grasses, is concentrated in the top 30 $\mathrm{cm}$ of soil, decreasing with depth from the surface. However, 
Table 1. Summary of the analysis of variances of the data for root dry mass (RDM), saturation extract electrical conductivity $\left(E_{\mathrm{e}}\right)$, sodium $(\mathrm{Na})$, calcium $(\mathrm{Ca})$, magnesium $(\mathrm{Mg})$, chloride $(\mathrm{Cl})$, potassium $(\mathrm{K})$, and nitrate $\left(\mathrm{NO}_{3}\right)$, in soil cultivated with maize as related to different levels of salinity, nitrogen rates, and soil layers

\begin{tabular}{|c|c|c|c|c|c|c|c|c|c|}
\hline \multirow{2}{*}{ SV } & \multirow{2}{*}{ DF } & \multicolumn{8}{|c|}{ Mean squares } \\
\hline & & $\mathrm{RDM}^{1}$ & $\mathrm{EC}_{\mathrm{e}}$ & $\mathrm{Na}$ & $\mathrm{Ca}$ & $\mathrm{Mg}$ & $\mathrm{CI}$ & K & $\mathrm{NO}_{3}$ \\
\hline Block & 3 & $2.31^{* *}$ & $0.35^{\text {ns }}$ & $57.55^{\text {ns }}$ & $33.86^{\text {ns }}$ & $12.43^{\text {ns }}$ & $52.40^{\text {ns }}$ & $0.32^{\star \star}$ & $8540.93^{\text {ns }}$ \\
\hline Salinity (S) & 3 & $18.85^{\star *}$ & $602.05^{\star *}$ & $12402.85^{* *}$ & $9257.81^{* *}$ & $1652.22^{* *}$ & $60027.88^{* *}$ & $1.69 * *$ & $429679.23^{* *}$ \\
\hline Nitrogen (N) & 3 & $0.421^{\text {ns }}$ & $6.01^{* *}$ & $78.90^{\star}$ & $210.63^{\star *}$ & $27.23^{\star}$ & $12.06^{\text {ns }}$ & $0.047^{*}$ & $3283250.54^{* *}$ \\
\hline Layer $(\mathrm{L})$ & $3(2)$ & $124.63^{\star *}$ & $368.73^{\star *}$ & $3645.25^{\star *}$ & $16803.36^{* *}$ & $3472.97^{* *}$ & $36461.73^{* *}$ & $0.658^{* *}$ & $212734.58^{* *}$ \\
\hline Interation (SxN) & 9 & $0.63^{\mathrm{ns}}$ & $1.20^{\text {ns }}$ & $31.21^{\mathrm{ns}}$ & $27.43^{\text {ns }}$ & $4.73^{\text {ns }}$ & $180.43^{\text {ns }}$ & $0.028^{*}$ & 109396.97 ** \\
\hline Interation (SXL) & $9(6)$ & $8.76^{\star *}$ & $41.40^{* *}$ & $1486.06^{\star *}$ & $1966.04^{* *}$ & $379.89 * *$ & $4527.51^{* *}$ & $0.259^{* *}$ & $96982.79 * *$ \\
\hline Interation (NxL) & $9(6)$ & $0.296^{\mathrm{ns}}$ & $3.06^{* *}$ & $41.96^{\text {ns }}$ & $175.58 * *$ & $26.32^{* \star}$ & $212.93^{* *}$ & $0.022^{\mathrm{ns}}$ & $246939.99 * *$ \\
\hline Interation (SxNxL) & $27(18)$ & $0.407^{\mathrm{ns}}$ & $0.77^{\mathrm{ns}}$ & $21.24^{\mathrm{ns}}$ & $37.98^{\text {ns }}$ & $7.12^{\text {ns }}$ & $151.87^{\mathrm{ns}}$ & $0.011^{\mathrm{ns}}$ & $33713.07^{* *}$ \\
\hline Error & $189(141)$ & 0.378 & 1 & 21.82 & 52.37 & 8.76 & 175.21 & 0.0124 & 7558.48 \\
\hline C.V (\%) & - & 44.89 & 19.77 & 21.84 & 35.75 & 33.82 & 33.04 & 23.48 & 26.87 \\
\hline
\end{tabular}

ns, $* \star,{ }^{*}$ No-significant and significant at 0,01 and 0,05 probability by the F test, respectively; DF - Degrees of freedom; "( )" - Values of degree of freedom and error used for the root dry mass (RDM) (determined for only 3 soil layers); "1" - Root dry mass (found only until the third layer of soil); C.V - Coefficient of variation

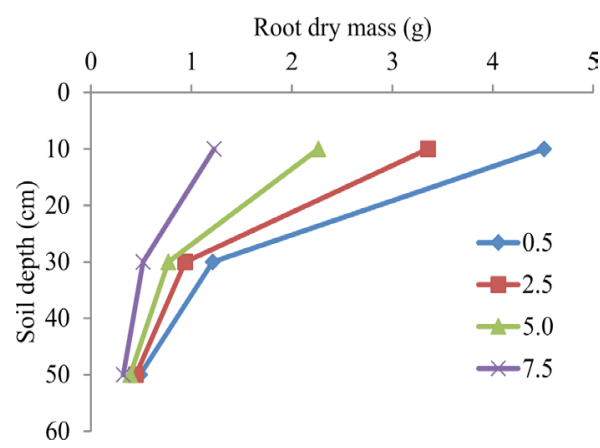

Figure 1. Effect of salinity of irrigation water $(0.5,2.5,5$ and $7.5 \mathrm{dS} \mathrm{m}^{-1}$ ) and soil depth on root dry mass per plant

the decrease in root dry mass was accentuated by the increase in the salt concentration in the irrigation water, as verified by the statistically significant interaction S x L (Table 1). This effect became more evident in the first $10 \mathrm{~cm}$ of the soil, where the plants that received low-salt irrigation water $\left(0.5 \mathrm{dS} \mathrm{m}^{-1}\right)$ had 4.5 $\mathrm{g}$ of roots while the treatment with the highest concentration of salts had a mean of $1.2 \mathrm{~g}$.

Salinity is one of the main factors that reduce crop productivity. Inhibition of plant growth (root and shoot) due to salt-stress may be caused by the reduction of osmotic potential and/or excessive accumulation of ions, which may induce ionic toxicity, nutritional imbalance or both (Munns \& Tester, 2008; Lacerda et al., 2016b). Salinity effects (osmotic, toxic and nutritional) reduce the net assimilation of $\mathrm{CO}_{2}$, accelerate the senescence of mature leaves, and inhibit leaf expansion, thus reducing the area destined to the photosynthetic process (Lacerda et al., 2003; Munns \& Tester, 2008).

The soil chemical characteristics were affected by the treatments, as evidenced by the increase in the electrical conductivity of the soil-saturated extract as a function of salinity of irrigation water (Figure 2A). As expected, the highest $\mathrm{EC}_{\mathrm{e}}$ values were observed in the treatment with the highest salt concentration $\left(\mathrm{S} 4=7.5 \mathrm{dS} \mathrm{m} \mathrm{m}^{-1}\right)$, while the lowest values occurred in the treatments with lower salt concentrations, respectively, $\mathrm{S} 1\left(0.5 \mathrm{dS} \mathrm{m}^{-1}\right)$ and $\mathrm{S} 2\left(2.5 \mathrm{dS} \mathrm{m}^{-1}\right)$. It was also verified that the increase in $\mathrm{EC}_{\mathrm{e}}$ in deeper soil layers was caused mainly by the downwards flow of the irrigation water causing the leaching of salts and increase in $\mathrm{EC}_{\mathrm{e}}$ with depth (Figure 2A).

Water entering the soil is able to solubilize the chemical elements (mainly the chlorides and sulphates) in the upper part

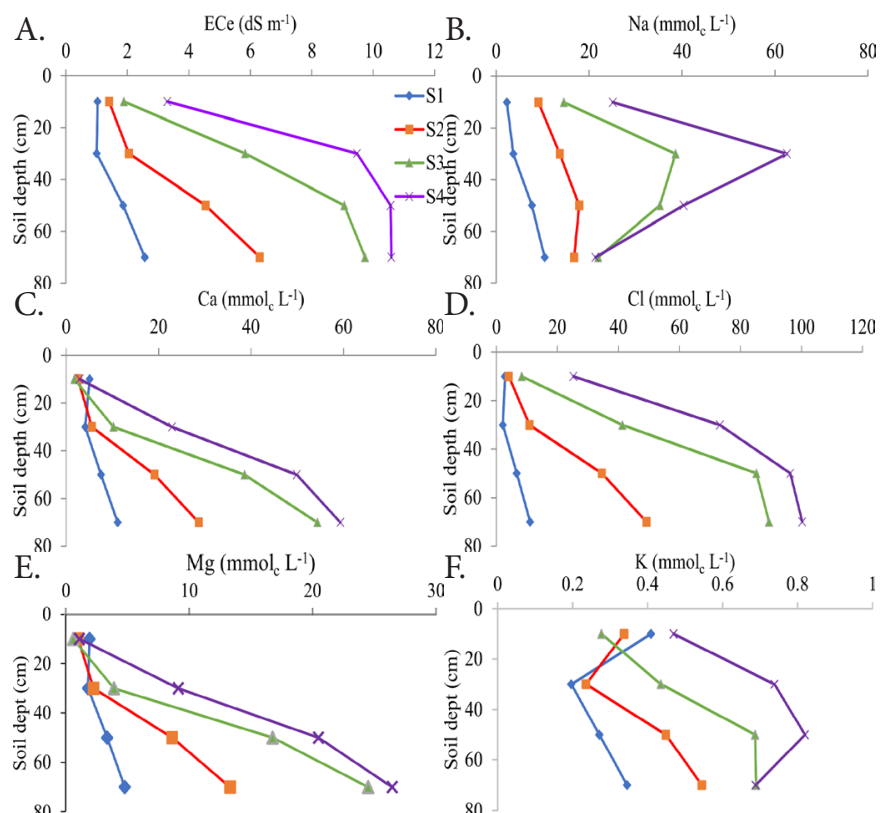

Figure 2. Electrical conductivity (A), soluble $\mathrm{Na}(\mathrm{B})$, soluble $\mathrm{Ca}(\mathrm{C})$, soluble $\mathrm{Cl}(\mathrm{D})$, soluble $\mathrm{Mg}(\mathrm{E})$ and soluble $\mathrm{K}(\mathrm{F})$ in saturation extract of soil in different depths as a function of irrigation water salinity (S1 - 0.5; S2 - 2.5; S3 - 5.0 and $\mathrm{S} 4-7.5 \mathrm{dS} \mathrm{m}^{-1}$ )

of the profile and translocate them to deeper layers (Brady \& Weil, 2013; Mendes et al., 2016). Irrigation water itself (saline or brackish water) contributes to the increase in salt concentration and, consequently, to the increase in soil electrical conductivity (Ayers \& Westcot, 1999).

An increase was observed in the concentration of soluble sodium, calcium, magnesium and chloride in the soil with increasing irrigation water salinity (Figures $2 \mathrm{~B}, \mathrm{C}, \mathrm{D}$ and $\mathrm{E}$ ). This trend is due to the chemical composition of the saline waters used for irrigation. According to Medeiros et al. (2016), the main elements present in saline water are the cations $\mathrm{Na}^{+}$, $\mathrm{Ca}^{2+}$ and $\mathrm{Mg}^{2+}$ and the anions $\mathrm{Cl}^{-}, \mathrm{SO}_{4}{ }^{2-}$ and $\mathrm{HCO}_{3}$. Thus, the accumulation of $\mathrm{Ca}^{2+}, \mathrm{Mg}^{2+}, \mathrm{Cl}^{-}$and, especially $\mathrm{Na}^{+}$in soils irrigated with saline waters is to be expected, and the higher the concentration of these elements in the irrigation water, the greater the accumulation of these constituents in the soil (Ayers \& Westcot, 1999). 
All treatments received the same amount of potassium, but the potassium distribution in the soil was similar to that of other cations, that is, more accentuated in the treatments with higher concentration of salts (Figure $2 \mathrm{~F}$ ) and higher nitrogen rates (Figure 3).

The largest $\mathrm{K}$ concentrations occurred in the treatment with the highest $\mathrm{N}$ and salt in the irrigation water (Figure 3). The concentration of $\mathrm{K}$ in the soil extracts of the S4N1 treatment was approximately $153 \%$ greater than found in the treatments with lower $\mathrm{N}$ levels and lower salt concentration (S1N2 and S1N4). Root growth under salt-stress was restricted by both the osmotic and toxic effects of the salt ions (Figure 1), which resulted in lower nutrient uptake by plants and inhibited translocation of mineral nutrients, especially $\mathrm{K}$ (Figures $2 \mathrm{~F}$ and Figure 3). Shabala \& Cuin (2008) attributed the low potassium use efficiency in plants under salt stress to the physicochemical similarities between $\mathrm{Na}^{+}$and $\mathrm{K}^{+}$. According to the authors, sodium competes with potassium inside the plant for ionic transport sites and metabolic processes.

Low nitrate accumulation $\left(\mathrm{NO}_{3}^{-}\right)$in the soil was recorded in treatments with different $\mathrm{N}$ rates and irrigation using fresh water (S1N1, S1N2, S1N3 and S1N4) (Figure 4A), especially in treatments with reduced amounts of $\mathrm{N}$ (S1N2 and S1N4).

Nitrate was the only evaluated parameter that presented a significant interaction (salinity $\mathrm{x}$ soil layer $\mathrm{x} \mathrm{N}$ rate), as shown in Table 1. In treatments with higher levels of nitrogen (N1 and $\mathrm{N} 3$ ), $\mathrm{NO}_{3}{ }^{-}$accumulation was observed in the deeper regions of the soil. This effect became more evident when higher salt concentrations were used (starting at $2.5 \mathrm{dS} \mathrm{m}^{-1}$ ), according to Figures $4 \mathrm{~B}, \mathrm{C}$ and $\mathrm{D}$. In the treatment with saline water $\left(7.5 \mathrm{dS} \mathrm{m}^{-1}\right)$ and $100 \%$ of $\mathrm{N}$ recommendation for maize crop (S4N1), $88 \%$ of nitrate was below $20 \mathrm{~cm}$ of soil depth.

The soil extract results showed a high loss of $\mathrm{N}$ due to the leaching of $\mathrm{NO}_{3}^{-}$, as well as to the low $\mathrm{N}$ utilization by the

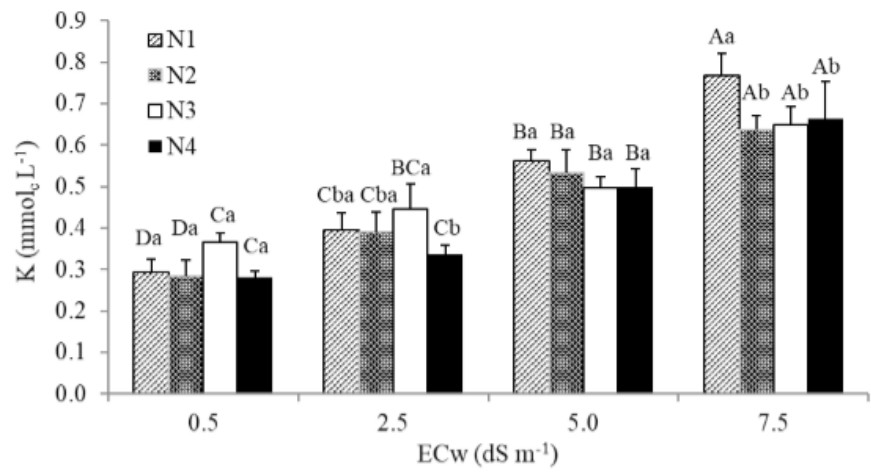

Capital letters identify statistical differences for different salinity treatments at the same $\mathrm{N}$ application. Lowercase letters identify statistical differences for different $\mathrm{N}$ application treatments at the same salinity level

Figure 3. Mean values of potassium concentration in the soil saturation extracts in response to the combination of four levels (S1 to S4) of salinity $(0.5,2.5,5.0$ and 7.5 $\left.\mathrm{dS} \mathrm{m}^{-1}\right)$, and four rates of $\mathrm{N}(\mathrm{N} 1-\mathrm{N}$ recommendation for maize ( 2.6 g column $\left.^{-1}\right)$; N2 - 0.3 times of recommendation $\mathrm{N} 1\left(0.78\right.$ g column $\left.^{-1}\right) ; \mathrm{N} 3$ and N4 - Reduced rate of $\mathrm{N} 1$ and $\mathrm{N} 2$, respectively, based on the reduction in evapotranspiration caused by salinity. Each bar represents the average value of the four layers of soil

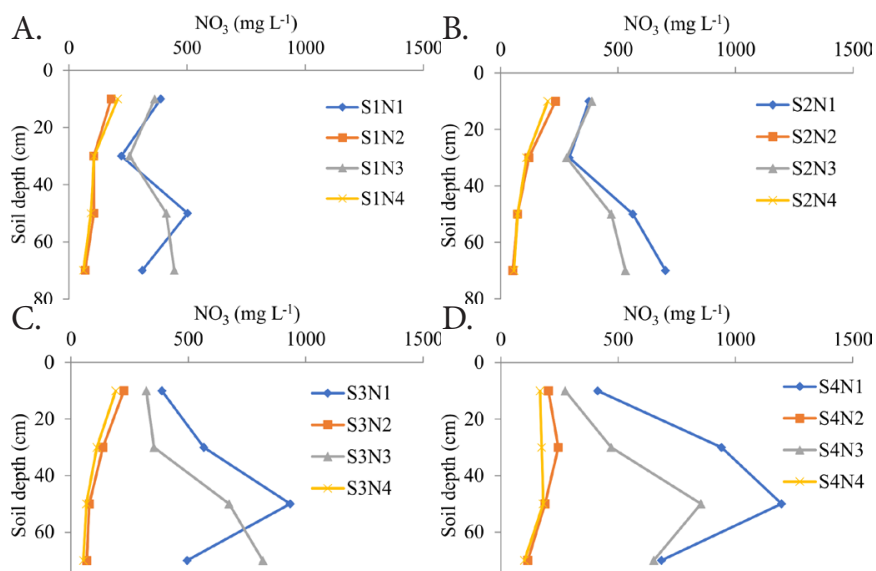

80

80

Figure 4. Soil nitrate accumulation caused by irrigation water salinity and four rates of nitrogen (N1 to N4). A - 0.5 (S1); $\mathrm{B}$ - 2.5 (S2); C - 5.0 (S3); D - 7.5 dS m-1 (S4)

crop under saline irrigation. Under salt-stress conditions, the processes of absorption and assimilation of nutrients by plants are affected, mainly nitrate, which is the main source of nitrogen in agricultural soils and, most frequently, limits the growth of plants (Meloni et al., 2004). The marked reduction in root growth in treatments with elevated salinity (Figure 1) reduces the potential of utilization of $\mathrm{N}$ and others nutrients (Shenker et al., 2003; Segal et al., 2010; Ramos et al., 2012). Moreover, the increase in electrical conductivity can affect the movement of nutrients in the soil because it reduces its displacement by mass flow, mainly restricting nitrogen and potassium uptake (Santos et al., 2016).

Nutrients losses by leaching below the root zone may be more significant in systems where plants are subject to saline stress. In this situation, plants tend to decrease growth and water use, mainly due to the osmotic effects and salinity toxicity of sodium and chloride (Lacerda et al., 2003; Munns \& Tester, 2008; Lacerda et al., 2016b). Furthermore, leaching losses had the most significance for nutrients needed in higher concentrations by the plant (such as N) and fertilizers highly soluble in water, such as containing nitrate.

\section{Conclusions}

1. Nitrate and potassium accumulation, especially in the soil layers below $20 \mathrm{~cm}$ depth, was observed in the treatments with high salinity, evidence of losses of these elements by leaching below the rootzone.

2. The increase in electrical conductivity of irrigation water caused a significant reduction in maize root biomass, especially in the upper $20 \mathrm{~cm}$ of soil.

\section{ACKnOWledgments}

Authors acknowledge the Conselho Nacional de Desenvolvimento Científico e Tecnológico (CNPq), Instituto Nacional de Ciência e Tecnologia em Salinidade (INCTSal), and Universidade Federal do Ceará, Brazil, for financial support provided to the senior author. Additional support, such as technical assistance and consumables, was provided by US Salinity Laboratory (ARS/USDA). 


\section{Literature Cited}

AOAC - Association of Official Agricultural Chemists. Official methods of analysis. 15.ed. Washington: AOAC, 1990. 1289p.

Ayers, R. S.; Westcot, D. W. A qualidade de água na agricultura. 2.ed. Campina Grande: UFPB, 1999. 153p.

Azevedo Neto, A. D. de; Tabosa, J. N. Estresse salino em plântulas de milho: Parte II - Distribuição dos macronutrientes catiônicos e suas relações com sódio. Revista Brasileira de Engenharia Agrícola e Ambiental, v.4, p.165-171, 2000. https://doi. org/10.1590/S1415-43662000000200006

Brady, N. C.; Weil, R. R. Elementos da natureza e propriedades dos solos. 3.ed. Porto Alegre: Bookman, 2013. 704p.

Cataldo, D. A.; Haroon, M.; Schrader, L. E.; Youngs, V. L. Rapid colorimetric determination of nitrate in plant tissue by nitration of salicylic acid. Communications in Soil Science and Plant Analysis, v.6, p.71-80, 1975. https://doi.org/10.1080/00103627509366547

Gaines, T. P.; Paker, M. B.; Gascho, G. J. Automated determination of chorides in soil and plant tissue by sodium nitrate extration. Agronomy Journal, v.76, p.371-374, 1984. https://doi.org/10.2134/ agronj1984.00021962007600030005x

Grattan, S. R.; Grieve, C. M. Salinity-mineral nutrient relations in horticultural crops. Scientia Horticulturae, v.78, p.127-157, 1999. https://doi.org/10.1016/S0304-4238(98)00192-7

$\mathrm{Hu}, \mathrm{Y}$;; Schmidhalter, U. Drought and salinity: A comparison of their effects on mineral nutrition of plants. Journal of Plant Nutrition and Soil Science, v.168, p.541-549, 2005. https://doi.org/10.1002/ jpln.200420516

Irshad, M.; Eneji, A. E.; Yasuda, H. Comparative effect of nitrogen sources on maize under saline and non-saline conditions. Journal of Agronomy and Crop Science, v.194, p.256-261, 2008. https:// doi.org/10.1111/j.1439-037X.2008.00310.x

Lacerda, C. F. de; Cambraia, J.; Oliva, M. A.; Ruiz, H. A.; Prisco, J. T. Solute accumulation and distribution during shoot and leaf development in two sorghum genotypes under salt stress. Environmental and Experimental Botany, v.49, p.107-120, 2003. https://doi.org/10.1016/S0098-8472(02)00064-3

Lacerda, C. F. de; Costa, R. N. T.; Bezerra, M. A.; Neves, A. L. R.; Sousa, G. G. de; Gheyi, H. R. Estratégias de manejo para uso de água salina na agricultura. In: Gheyi, H. R.; Dias, N. da S.; Lacerda, C. F. de; Gomes Filho, E. Manejo da salinidade na agricultura: Estudo básico e aplicados. 2.ed. Fortaleza: INCTSal, 2016a. Cap.21, p.337-352.

Lacerda, C. F. de; Ferreira, J. F. S.; Liu, X.; Suarez, D. L. Evapotranspiration as a criterion to estimate nitrogen requirement of maize under salt stress. Journal of Agronomy and Crop Science, v.202, p.192-202, 2016b. https://doi.org/10.1111/jac. 12145

Medeiros, J.F.; Gheyi, H.R.; Costa, A.R.F.C.; Tomaz, H.V.C. Manejo do solo-água-planta em áreas afetadas por sais. In: Gheyi, H. R.; Dias, N. da S.; Lacerda, C. F. de; Gomes Filho, E. Manejo da salinidade na agricultura: Estudo básico e aplicados. 2.ed. Fortaleza: INCTSal, 2016. Cap.20, p.319-335.
Meloni, D. A.; Gulotta, M. R.; Martínez, C. A.; Olivia, M. A. The effects of salt stress on growth, nitrate reduction and proline and glycinebetaine accumulation in Prosopis alba. Brazilian Journal Plant Physiology, v.16, p.39-46, 2004. https://doi.org/10.1590/ S1677-04202004000100006

Mendes, W. da C.; Alves Júnior, J.; Cunha, P. C. R. da; Silva, A. R. da; Evangelista, A. W. P.; Casaroli, D. Potassium leaching in different soils as a function of irrigation depths. Revista Brasileira de Engenharia Agrícola e Ambiental, v.20, p.972-977, 2016. https:// doi.org/10.1590/1807-1929/agriambi.v20n11p972-977

Munns, R.; Tester, M. Mechanisms of salinity tolerance. Annual Review of Plant Biology, v.59, p.651-668, 2008. https://doi. org/10.1146/annurev.arplant.59.032607.092911

Prisco, J. T.; Gomes Filho, E.; Miranda, R. de S. Physiology and biochemistry of plants growing under salt stress. In: Gheyi, $\mathrm{H}$. R.; Dias, N. da S.; Lacerda, C. F. de; Gomes Filho, E. Manejo da salinidade na agricultura: Estudo básico e aplicados. 2.ed. Fortaleza: INCTSal, 2016. Cap.12, p.163-180.

Ramos, T. B.; Simunek, J.; Gonçalves, M. C.; Martins, J. C.; Prazeres, A.; Pereira, L. S. Two-dimensional modeling of water and nitrogen fate from sweet sorghum irrigated with fresh and blended saline waters. Agricultural Water Management, v.111, p.87-104, 2012. https://doi.org/10.1016/j.agwat.2012.05.007

Richards, L. A. Diagnosis and improvement of saline and alkali soils. Washington: United States Salinity Laboratory, 1954. 160p.

Santos, R. V.; Cavalcante, L. F.; Vital, A. F. M.; Lacerda, C. F. de; Souza, E. R. de; Lima, G, S. de. Interações salinidade-fertilidade do solo. In: Gheyi, H. R.; Dias, N. da S.; Lacerda, C. F. de; Gomes Filho, E. Manejo da salinidade na agricultura: Estudo básico e aplicados. 2.ed. Fortaleza: INCTSal, 2016. Cap.18, p.277-294.

Segal, E.; Shouse, P.; Poss, J. A.; Crohn, D. M.; Bradford, S. A. Recommendations for nutrient management plans in a semi-arid environment. Agriculture Ecosystems \& Environment, v.137, p.317-328, 2010. https://doi.org/10.1016/j.agee.2010.03.002

Shabala, S.; Cuin, T. A. Potassium transport and plant salt tolerance. Physiologia Plantarum, v.133, p.651-669, 2008. https://doi. org/10.1111/j.1399-3054.2007.01008.x

Shenker, M.; Ben-Gal, A.; Shani, U. Sweet maize response to combined nitrogen and salinity environmental stresses. Plant Soil, v.256, p.139-147, 2003. https://doi.org/10.1023/A:1026274015858

Tagliaferre, C.; Guimarães, D. U. G.; Gonçalves, L. J.; Amorim, C. H. F.; Campos, W. V.; Rocha, F. A. Absorption of nutrients by cowpea irrigated with saline water under different leaching fractions. Revista Brasileira de Engenharia Agrícola e Ambiental, v.20, p.1067-1071, 2016. https://doi.org/10.1590/1807-1929/agriambi. v20n12p1067-1071

Willadino, L.; Camara, T. R. Tolerância das plantas à salinidade: Aspectos fisiológicos e bioquímicos. Enciclopédia Biosfera, v.6, p.1-23, 2010. 